Journal of Teacher Education for Sustainability, vol. 16, no. 2, pp. 71-87, 2014

\title{
Teachers' Facility with Evidence-Based Classroom Management Practices: An Investigation of Teachers' Preparation Programmes and In-service Conditions
}

\author{
Laura Ficarra and Kevin Quinn \\ University at Albany, State University of New York, \\ the United States of America
}

\begin{abstract}
In the present investigation, teachers' self-reported knowledge and competency ratings for the evidence-based classroom management practices were analysed. Teachers also reflected on how they learned evidence-based classroom management practices. Results suggest that teachers working in schools that implement Positive Behavioural Interventions and Supports (PBIS) had significantly higher mean knowledge ratings in the area of posting, teaching, reviewing, monitoring and reinforcing expectations than those who do not teach in a PBIS school. Teachers certified in special education had significantly higher knowledge and competency ratings in relation to maximising structure, using a continuum of strategies to acknowledge appropriate behaviour and employing a variety of techniques to respond to inappropriate behaviour than those not certified in special education. Teachers' knowledge of each of these practices came mostly from in-service sources. Implications of these findings for teachers' preparation in classroom management are discussed.
\end{abstract}

Keywords: classroom management, teacher education, special education, Positive Behavioral Interventions and Supports (PBIS), evidence-based

\section{Recommended Practices for Classroom Management}

For teachers to provide effective instruction that meaningfully resonates with students, the classroom environment must include skillful management of students' taskrelated behavior (McIntosh, Chard, Boland, \& Horner, 2006; McIntosh, Horner, Chard, Dickey, \& Braun, 2008). Without adequate classroom management skills, the execution of an otherwise well-conceived lesson may be easily thwarted; one may ask, therefore, "If a teacher offers instruction without proficiency in classroom management, does student learning occur?”

Classroom management is a comprehensive construct defined as "...the actions teachers take to create an environment that supports and facilitates both academic and social emotional learning" (Evertson \& Weinstein, 2006, p. 1044). Schools and the 
classrooms within them, are crucial environments for prevention and early intervention efforts for students who experience problematic development with both academic and social-emotional behavior (Levine, 2006; McIntosh et al., 2006; Oliver \& Reschly, 2007; Walker \& Severson, 2002). Given the influence of such environments, effective classroom management must be part of the support regimen to foster desired learning and behavioural outcomes. Classroom management techniques need to be responsive as well as reflect best practice and theory. To provide effective supports using proactive and preventative logic, teachers must engage mindfully in evidence-based classroom management practices (Moore-Partin, Robertson, Maggin, Oliver, \& Wehby, 2010).

In an extensive and rigorous review of the literature to determine evidence-based practices in classroom management, Simonsen, Fairbanks, Briesch, Myers and Sugai (2008) identified 20 key strategies. The five critical elements, herein referred to as subscales, of evidence-based classroom management are: 1) maximising structure; 2) posting, teaching, reviewing, monitoring and reinforcing expectations; 3 ) engaging students actively in observable ways; 4 ) using a continuum of strategies to acknowledge appropriate behavior and 5) employing a variety of techniques to respond to inappropriate behaviour. The operationalisations of the practices that comprise these five subscales are presented in Appendix A. Despite these known and proven strategies and actions, evidence indicates teachers often do not use these particular practices. Kennedy and Thomas (2012) have posited that a key reason teachers do not adopt evidence-based practices in classroom management is that their pre-service preparation in this domain is inadequate.

\section{Pre-service Preparation in Classroom Management}

Although instruction in classroom management has been identified as an essential component of pre-service teachers' preparation (Auld, Belfiore, \& Scheeler, 2010; Kennedy \& Thomas, 2012), the inclusion of classroom management within required components of teacher preparation has been and continues to be inadequate (Levine, 2006; Oliver \& Reschly, 2007, 2010). Across all elementary and secondary schools, formal, accredited higher education coursework is not a common source for learning and practicing classroom management skills (Smart \& Igo, 2010); only 18\% of teachers report that they learned the skills as part of their teacher preparation programme (Merrett $\&$ Wheldall, 1993), and only $27 \%$ of teachers' preparation programmes offer an entire course on the topic of classroom management (Oliver \& Reschly, 2010). The effects of sparse coursework in classroom management are compounded by insufficient opportunities to practice implementing strategies during field placements that offer direct instruction, coaching and feedback (Capizzi, Wehby, \& Sandmel, 2010; Moore-Partin et al., 2010; Oliver, Wehby, \& Reschly, 2011; Simonsen, MacSuga, Fallon, \& Sugai, 2012; Simonsen, Myers, \& DeLuca, 2010).

Researchers have indicated that there appear to be nuances in the preparation of general and special educators. General education majors have reported little to no preparation in classroom management, and the minimal preparation they do get in reinforcement basics is almost exclusively offered within special education courses (Brownell, Smith, McNellis, \& Miller, 1997; Kennedy \& Thomas, 2012; Tillery, Varjas, Meyers, \& Collins, 2010). Within special education teacher preparation programmes, encouraging prosocial behaviour and reducing troubled students' behaviour were emphasised, and 
five percent of special educators reported having one entire class dedicated to classroom management as an undergraduate (Oliver \& Reschly, 2010; Tillery et al., 2010). Therefore, a general education teacher may not receive coursework in classroom management to the extent that a special education teacher might.

\section{In-service Opportunities in Classroom Management}

Professional development (PD) within educational settings is an administrative investment in human capital so that knowledge and skills can continue to develop in situ (Leana, 2011). Teachers have persistently identified classroom management as an area for which they need additional on-site training that will establish or further develop skills not sufficiently addressed in pre-service programmes (Reinke, Stormont, Herman, Puri, \& Goel, 2011; Tillery et al., 2010).

Teachers also report that they learn from colleagues as well as from outside experts while on-the-job and actually favor the former method (Frey, Park, Browne-Ferrigno, \& Korfhage, 2010). Teachers reported consulting with a colleague or mentor to be a preferred method for learning new strategies (Clunies-Ross, Little, \& Kienhuis, 2008; Tillery et al., 2010). Merrett and Wheldall (1993) found that $82 \%$ of teachers developed classroom management skills by encountering certain behavioural situations and then collaborating with peers to formulate solutions. Second only to students' teaching, first-year teachers reported that trial-and-error classroom experience was the most common way classroom management skills were learned (Smart \& Igo, 2010).

As part of the current reform efforts in schools, Positive Behavioral Interventions and Supports is a framework that organises effective supports for students' outcomes (Horner \& Sugai, 2000). The multi-tiered Positive Behavioral Interventions and Supports (PBIS) framework is evidence-based and emphasises proactively supporting all students. This model involves preventing difficulties by addressing environmental arrangements, teaching expectations, reinforcing appropriate behavior and extinguishing inappropriate behaviour. The PBIS framework also offers an operationalised structure for conceptualising the development and implementation with fidelity of a continuum of behavioural supports for all students as a means of scaffolding both instructional and social outcomes (Sugai, 2009). The multi-tiered dimension of the PBIS model encourages the intensity of service provided to match the intensity of the student's needs. Effective classroom management practices, such as those previously noted, are at the universal level of PBIS.

\section{Factors Affecting Teachers' Practices}

For teachers to be effective resources for one another regarding classroom management, they need to first possess reasonable capacity in this area. Although knowledge of an intervention strategy is a prerequisite to actually using the strategy, awareness of a strategy does not necessarily correlate with application of the strategy (Peters, 2009). As noted by Reupert and Woodcock (2010), the strategies that teachers use will be influenced by their perceived knowledge and competency with those strategies; that is, teachers often use strategies with which they consider themselves competent. 


\section{Teachers' Knowledge of Strategies}

Researchers have found that teachers who are skilled at classroom management address behaviour issues using both preventative and intervention techniques that empower students to grapple with the issues giving rise to the behavior (Brophy \& McCaslin, 1992). Most teachers, however, self-report reliance on less effective practices such as aversive and reactive consequences (Tillery et al., 2010). Researchers have also indicated that teachers use a fairly limited range of classroom management strategies (Frey et al., 2010) focusing on reactive practices (Tillery et al., 2010).

\section{Teachers' Competency Using Strategies}

Teachers' confidence in their competency impacts their willingness to intervene with varying levels of students' needs (Hamill \& Dever, 1998). According to Reupert and Woodcock (2010), in-service teachers utilise classroom management practices in which they feel confident applying, even if other strategies had been shown to be more effective. In a study conducted by Westling (2010), it was found that the number of strategies teachers used to address troubling students' behaviour and their confidence levels using such could be predicted by their pre- and in-service experiences (Westling, 2010).

\section{Purpose}

There is a distinct emphasis on teachers' use of evidence-based practices in the education field today; however, little is known about teachers' perceived knowledge of and competence in skill sets in classroom management that have been empirically shown to support students' social-emotional behaviour. Furthermore, the questions of when and how such skills are learned were studied by the authors of the present investigation.

\section{Methods}

The sample for this investigation consisted of currently certified and practicing New York State public school teachers of grades K-12. In this particular study, within each of the 10 geographic regions, all school districts were assigned a number for random selection. Using a stratified sample, the prospective teacher e-mail addresses were selected for each region; all members of the sample received an e-mail inviting them to participate in the study with a link to the electronic survey. In order to give recipients of the survey maximum opportunity to respond, two rounds of e-mails were distributed for a final response rate of $11.4 \%$. Other survey-based investigations reviewed suggested similar response rates for an online survey with no completion incentive from a sender that is personally unknown to recipients (i.e. 11\% - in Merrett \& Wheldall, 1993; 14.2\% - in O’Neill \& Stephenson, 2012).

In terms of participant demographics, $27.8 \%$ of the teachers who completed the survey reported that their current teaching assignment is in the K-5 grade range, $26.1 \%$ at $6-8$ and $44.3 \%$ - at $9-12$. In terms of teaching experience, $11.3 \%$ reported $0-3$ years, $12.2 \%$ had $4-6$ years, $17.4 \%$ taught between $7-10$ years, $20 \%$ had $11-14$ years and $36.5 \%$ of the respondents reported 15 or more years of teaching experience. Teachers 
with a bachelor's degree represented $7 \%$ of the respondents, $75.7 \%$ had a master's degree, $2.6 \%$ earned a doctoral degree, $11.3 \%$ had a Certificate of Advanced Standing (CAS), .9\% were National Board Certified Teachers, and 1.7\% had Administrator certification. Special education certification was held by $35.6 \%$ of the respondents, and $48.2 \%$ reported working in a PBIS school.

The survey utilised in this study was "The Survey of Effective Classroom Management Strategies", which is a multi-item, forced-choice instrument and is available from the first author. The strategies were based on the work of Simonsen et al. (2008), in which evidence-based classroom management practices were ascertained. Psychometrics disaggregated by scale and subscale are location in Appendix B.

\section{Results}

\section{Teachers’ Knowledge and Competency with Evidence-Based Practices}

Enumerated in Table 1 are the mean ratings for both knowledge and competency for each evidence-based classroom management practice. Practicing teachers, on average, reported their knowledge of evidence-based classroom management practices as being between the low-medium and medium-high (range: 1.70-2.82). Specifically, teachers reported being most knowledgeable about supervising classroom activities $(\overline{\mathrm{X}}=2.82)$ but least knowledgeable about response cards $(\overline{\mathrm{X}}=1.70)$ as a means of engaging students.

Teachers' reported competency across the practices also reflected low to medium and medium to high ratings (range: 1.32-2.79). Teachers reported they were most competent using the practice of actively supervising classroom activities $(\bar{X}=2.79)$ which, as just noted, was also the practice for which they reported being most knowledgeable. Teachers' self-reported competency ratings also reflected the smallest standard deviation $(s=.39)$, indicating ratings that were generally close to the mean. Teachers perceived themselves to be least competent in using token economies (for instance, students earn tokens that can later be redeemed for a prize or privilege) to acknowledge appropriate behavior $(\bar{X}=1.32)$, closely followed by the use of response cost, such as removing reinforcers that a student has previously-earned, for responding to inappropriate student behaviour $(\overline{\mathrm{X}}=1.33)$.

Table 1

Mean and Standard Deviations for Knowledge (K) and Competency (C) Ratings

\begin{tabular}{|c|c|c|c|c|c|}
\hline Concept (subscale) & Practices & K Mean & K SD & C Mean & C SD \\
\hline 1 & 2 & 3 & 4 & 5 & 6 \\
\hline \multirow[t]{2}{*}{ 1. Maximising structure } & $\begin{array}{l}\text { a. Establish structure through } \\
\text { teacher-directed activities }\end{array}$ & 2.65 & .66 & 2.70 & .49 \\
\hline & $\begin{array}{l}\text { b. Physical arrangement that } \\
\text { minimises distractions }\end{array}$ & 2.39 & .75 & 2.56 & .64 \\
\hline \multirow{2}{*}{$\begin{array}{l}\text { 2. Posting, teaching, } \\
\text { reviewing, monitoring } \\
\text { and reinforcing } \\
\text { expectations }\end{array}$} & $\begin{array}{l}\text { a. Develop and directly teach } \\
\text { expectations }\end{array}$ & 2.14 & .93 & 2.22 & .84 \\
\hline & $\begin{array}{l}\text { b. Actively supervise in all areas; } \\
\text { provide feedback on expectations }\end{array}$ & 2.82 & .39 & 2.79 & .47 \\
\hline
\end{tabular}


Sequel to Table 1.

\begin{tabular}{|c|c|c|c|c|c|}
\hline 1 & 2 & 3 & 4 & 5 & 6 \\
\hline \multirow{6}{*}{$\begin{array}{l}\text { 3. Engaging students } \\
\text { actively in observable } \\
\text { ways }\end{array}$} & a. Opportunities to respond & 2.51 & .62 & 2.50 & .78 \\
\hline & b. Response cards & 1.70 & 1.00 & 1.55 & 1.10 \\
\hline & c. Direct instruction of skills & 2.49 & .70 & 2.44 & .80 \\
\hline & d. Computer-assisted instruction & 1.99 & .88 & 1.99 & .92 \\
\hline & e. Class-wide peer tutoring & 1.84 & .84 & 1.57 & .99 \\
\hline & f. Guided notes & 2.22 & .85 & 2.03 & .96 \\
\hline \multirow{4}{*}{$\begin{array}{l}\text { 4. Using a continuum of } \\
\text { strategies to acknowledge } \\
\text { appropriate behaviour }\end{array}$} & a. Behaviour-specific praise & 2.64 & .54 & 2.68 & .49 \\
\hline & b. Class-wide contingencies & 1.99 & 1.02 & 1.64 & 1.11 \\
\hline & c. Behavioural contracts & 2.22 & .87 & 1.83 & 1.14 \\
\hline & d. Token economies & 1.99 & 1.12 & 1.32 & 1.24 \\
\hline \multirow{6}{*}{$\begin{array}{l}\text { 5. Employing a variety } \\
\text { of techniques to respond } \\
\text { to inappropriate } \\
\text { behaviour }\end{array}$} & $\begin{array}{l}\text { a. Error correction for academic } \\
\text { and social behavior }\end{array}$ & 1.97 & .89 & 1.66 & 1.10 \\
\hline & b. Performance feedback & 1.84 & .88 & 1.60 & 1.15 \\
\hline & $\begin{array}{l}\text { c. Differential reinforcement } \\
\text { techniques }\end{array}$ & 2.17 & .89 & 2.09 & .99 \\
\hline & d. Planned ignoring & 2.43 & .83 & 2.35 & .91 \\
\hline & e. Response cost & 1.87 & 1.10 & 1.33 & 1.14 \\
\hline & f. Time out from reinforcement & 2.01 & .91 & 1.83 & 1.06 \\
\hline
\end{tabular}

Note. 0 = none; 1 = low; 2 = medium; 3 = high

$* \mathrm{p}<.05$.

Presented in Table 2 are the correlations between teachers' reported knowledge and competency ratings for the evidence-based practices. Using Pearson's correlation coefficient guidelines, all correlations are positive with moderate to strong coefficients (range: .34-.75) with the percent of variability accounted for by the linear relationship between knowledge and competency ratings ranging between $12 \%$ and $56 \%$.

Table 2

Knowledge $(K)$ and Competency $(C)$ Rating Correlation Coefficients and $R^{2}$ Values

\begin{tabular}{|c|c|c|c|}
\hline Concept (subscale) & Practices & $\begin{array}{c}\text { K \& C } \\
\text { Correlation }\end{array}$ & $\mathrm{R}^{2}$ \\
\hline 1 & 2 & 3 & 4 \\
\hline \multirow[t]{2}{*}{ 1. Maximising structure } & $\begin{array}{l}\text { a. Establish structure through teacher-directed } \\
\text { activities }\end{array}$ & .56 & .31 \\
\hline & $\begin{array}{l}\text { b. Physical arrangement that minimises } \\
\text { distractions }\end{array}$ & .72 & .52 \\
\hline \multirow{2}{*}{$\begin{array}{l}\text { 2. Posting, teaching, } \\
\text { reviewing, monitoring } \\
\text { and reinforcing } \\
\text { expectations }\end{array}$} & a. Develop and directly teach expectations & .75 & .56 \\
\hline & $\begin{array}{l}\text { b. Actively supervise in all areas; provide } \\
\text { feedback on expectations }\end{array}$ & .58 & .34 \\
\hline \multirow{4}{*}{$\begin{array}{l}\text { 3. Engaging students } \\
\text { actively in observable } \\
\text { ways }\end{array}$} & a. Opportunities to respond & .63 & .40 \\
\hline & b. Response cards & .71 & .50 \\
\hline & c. Direct instruction of skills & .49 & .24 \\
\hline & d. Computer-assisted instruction & .67 & .45 \\
\hline
\end{tabular}


Sequel to Table 2.

\begin{tabular}{|c|c|c|c|}
\hline & e. Class-wide peer tutoring & .72 & .52 \\
\hline & f. Guided notes & .70 & .49 \\
\hline 4. Using a continuum of & a. Behaviour-specific praise & .34 & .12 \\
\hline strategies to acknowledge & b. Class-wide contingencies & .57 & .32 \\
\hline & c. Behavioural contracts & .63 & .40 \\
\hline & d. Token economies & .50 & .25 \\
\hline $\begin{array}{l}\text { 5. Employing a variety } \\
\text { of techniques to respond }\end{array}$ & $\begin{array}{l}\text { a. Error correction for academic and social } \\
\text { behavior }\end{array}$ & .34 & .12 \\
\hline to inappropriate & b. Performance feedback & .55 & .30 \\
\hline behaviour & c. Differential reinforcement techniques & .57 & .32 \\
\hline & d. Planned ignoring & .35 & .12 \\
\hline & e. Response cost & .65 & .42 \\
\hline & f. Time out from reinforcement & .56 & .31 \\
\hline
\end{tabular}

\section{Where Learning Evidence-based Classroom Management Practices Occurs}

For teachers who reported having knowledge of each strategy, their self-reported history reveals in-service as the main source of learning for evidence-based classroom management practices (Table 3). More specifically, the mean percentage of learning across the practices ranged from 49.3 to 74.3 for in-service learning and from 18.4 to 41.6 for pre-service. For all items, pre-service learning was lower than in-service learning. In-service experiences contributed most to computer-assisted instruction as a means of actual engagement of students $(\overline{\mathrm{X}}=74.3)$, whereas the mean percent of learning for that strategy via pre-service was 19.8 . For practices that participants reported as being addressed through pre-service preparation, the greatest contribution was to teachers' learning of direct skills instruction $(\overline{\mathrm{X}}=41.6 \%)$ and least to the use of response cards $(\overline{\mathrm{X}}=18.4 \%)$ to active engagement of students during instruction. The standard deviations of learning estimates from pre-service sources ranged from 15.57 to $26.99 \%$ and from 18.80 to $31.83 \%$ for in-service opportunities, which suggest highly variable experiences.

Table 3

Mean Learning Pre-and In-service Contributions for Each Evidence-Based Practice

\begin{tabular}{|c|c|c|c|c|c|}
\hline Concept (subscale) & Practices & 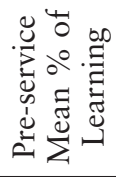 & Pre-SD & 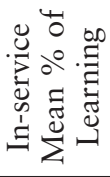 & In-SD \\
\hline 1 & 2 & 3 & 4 & 5 & 6 \\
\hline \multirow[t]{2}{*}{ 1. Maximising structure } & $\begin{array}{l}\text { a. Establish structure through } \\
\text { teacher-directed activities }\end{array}$ & 37.7 & 18.4 & 62.4 & 18.6 \\
\hline & $\begin{array}{l}\text { b. Physical arrangement that } \\
\text { minimises distractions }\end{array}$ & 25.1 & 18.0 & 67.6 & 24.9 \\
\hline \multirow{2}{*}{$\begin{array}{l}\text { 2. Posting, teaching, } \\
\text { reviewing, monitoring } \\
\text { and reinforcing } \\
\text { expectations }\end{array}$} & $\begin{array}{l}\text { a. Develop and directly teach } \\
\text { expectations }\end{array}$ & 29.9 & 22.8 & 68.0 & 26.7 \\
\hline & $\begin{array}{l}\text { b. Actively supervise in all areas; } \\
\text { provide feedback on expectations }\end{array}$ & 33.3 & 16.8 & 65.9 & 20.7 \\
\hline
\end{tabular}


Sequel to Table 3.

\begin{tabular}{|c|c|c|c|c|c|}
\hline 1 & 2 & 3 & 4 & 5 & 6 \\
\hline \multirow{6}{*}{$\begin{array}{l}3 \text {. Engaging students } \\
\text { actively in observable } \\
\text { ways }\end{array}$} & a. Opportunities to respond & 30.7 & 17.7 & 67.1 & 27.7 \\
\hline & b. Response cards & 18.4 & 15.6 & 59.6 & 31.8 \\
\hline & c. Direct instruction of skills & 41.6 & 24.9 & 59.3 & 22.0 \\
\hline & d. Computer-assisted instruction & 19.8 & 16.0 & 74.3 & 27.1 \\
\hline & e. Class-wide peer tutoring & 25.4 & 18.7 & 62.2 & 29.0 \\
\hline & f. Guided notes & 34.5 & 22.8 & 59.2 & 26.8 \\
\hline \multirow{4}{*}{$\begin{array}{l}\text { 4. Using a continuum of } \\
\text { strategies to acknowledge } \\
\text { appropriate behaviour }\end{array}$} & a. Behaviour-specific praise & 33.1 & 22.3 & 64.0 & 24.4 \\
\hline & b. Class-wide contingencies & 20.1 & 18.0 & 55.5 & 27.8 \\
\hline & c. Behavioural contracts & 29.5 & 24.3 & 65.3 & 27.1 \\
\hline & d. Token economies & 33.7 & 27.0 & 49.9 & 26.5 \\
\hline \multirow{6}{*}{$\begin{array}{l}\text { 5. Employing a variety } \\
\text { of techniques to respond } \\
\text { to inappropriate } \\
\text { behaviour }\end{array}$} & $\begin{array}{l}\text { a. Error correction for academic } \\
\text { and social behaviour }\end{array}$ & 27.6 & 24.3 & 57.2 & 27.2 \\
\hline & b. Performance feedback & 21.9 & 18.8 & 60.8 & 30.0 \\
\hline & $\begin{array}{l}\text { c. Differential reinforcement } \\
\text { techniques }\end{array}$ & 27.2 & 21.5 & 59.7 & 29.1 \\
\hline & d. Planned ignoring & 24.7 & 21.7 & 62.3 & 25.3 \\
\hline & e. Response cost & 24.0 & 22.8 & 49.2 & 25.5 \\
\hline & f. Time out from reinforcement & 25.4 & 20.1 & 59.6 & 26.3 \\
\hline
\end{tabular}

The sources of teachers' learning of the evidence-based classroom management practices were also examined more globally by subscale. As depicted in Figure 1, for each of the five subscales of evidence-based classroom management, teachers again estimated their learning as coming predominantly from in-service rather than from preservice experiences. Teachers self-reported a mean of $65.8 \%$ of their learning to come from in-service of practices associated with establishing structure, a mean of $67.17 \%$ of learning related to teaching and reinforcing expectations, a mean of $64.36 \%$ for learning related to engaging of students, a mean of $58.93 \%$ for learning of acknowledging appropriate behaviour techniques and a mean of $58.34 \%$ for learning responding to inappropriate students' behaviour.

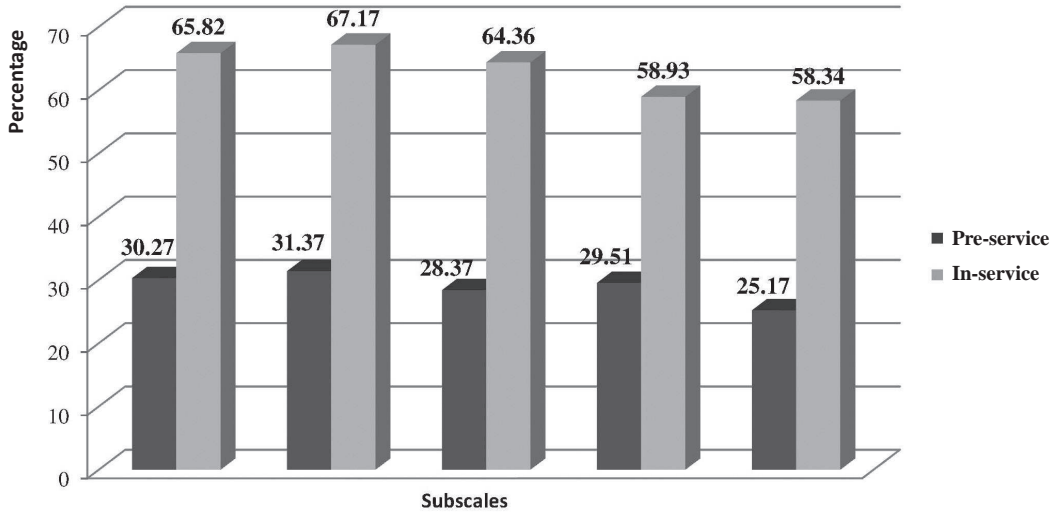

Structure (1) Expectations (2) Engagement (3) Appropriate Behaviours (4) Inappropriate Behaviours (5)

Figure 1. Means of teachers' self-reported learning estimates for each subscale of evidencebased classroom management through pre- and in-service opportunities 
Pre-service experiences provide fewer opportunities to learn these evidence-based classroom management techniques by contributing an average of $30.27 \%$ of teachers' learning of practices associated with structure, $31.37 \%$ for expectations, $28.37 \%$ for engagement of students, $29.51 \%$ for acknowledging appropriate behavior techniques and $25.17 \%$ for responding to inappropriate students' behaviour prior to entering the field. Note that the sums of the mean percentages for pre- and in-service experiences do not total $100 \%$ as teachers with no knowledge of the practice or from the specific preor in-service source reported $0 \%$ learning, and such instances (outliers) influenced the mean. These results suggest that given the number and variety of skills associated with effective evidence-based classroom management, pre-service preparation in this area will undoubtedly need to be supplemented by in-service endeavours.

\section{The Influence of PBIS on Teachers' Knowledge and Competency}

The mean self-reported knowledge and competency ratings by subscale for teachers working in a school that implements PBIS and for those who do not, are provided in Table 4. For each of the subscales, teachers who reported working in a PBIS school had descriptively higher means for both knowledge and competency ratings. An independent sample test of means indicated that the mean knowledge ratings of teachers in a PBIS school differed significantly from those not in PBIS schools only on the subscale area of post, teach, review, monitor and reinforce expectations $(\mathrm{t}=2.76, \mathrm{df}=75, \mathrm{p}<.05$; $\left.\omega^{2}=.08\right)$. Further inspection of the mean ratings for each group suggested that this difference is mainly driven by the practice of actively supervise in all areas; provide feedback on expectations of the two practices that compose this subscale. The mean knowledge ratings for all other subscales between those who taught in a PBIS school and those who did not were not significantly different. For mean competency ratings, the mean for all subscales between those who taught in a PBIS school and those who did not were not significantly different.

Table 4

Means, Standard Deviations, Test of Means and Omega Squared Values for Teachers' Knowledge (K) and Competency (C) Ratings for Each Subscale by PBIS School Status

\begin{tabular}{|c|c|c|c|c|c|c|c|c|}
\hline Concept (subscale) & K PBIS & $\begin{array}{l}\text { K Non- } \\
\text { PBIS }\end{array}$ & T-test & $\omega^{2}$ & C PBIS & $\begin{array}{l}\text { C Non- } \\
\text { PBIS }\end{array}$ & T-test & $\omega^{2}$ \\
\hline 1 & 2 & 3 & 4 & 5 & 6 & 7 & 8 & 9 \\
\hline $\begin{array}{l}\text { 1. Maximising } \\
\text { structure }\end{array}$ & $\begin{array}{l}\bar{X}=2.60 \\
s=.57\end{array}$ & $\begin{array}{l}\bar{X}=2.46 \\
\mathrm{~s}=.59\end{array}$ & $\mathrm{t}=1.02$ & .00 & $\begin{array}{l}\bar{X}=2.70 \\
s=.46\end{array}$ & $\begin{array}{l}\bar{X}=2.57 \\
s=.44\end{array}$ & $\mathrm{t}=1.26$ & .01 \\
\hline $\begin{array}{l}\text { 2. Posting, teaching, } \\
\text { reviewing, monito- } \\
\text { ring, and reinforcing } \\
\text { expectations }\end{array}$ & $\begin{array}{l}\bar{X}=2.66 \\
s=.39\end{array}$ & $\begin{array}{l}\bar{X}=2.33 \\
s=.62\end{array}$ & $\mathrm{t}=2.76^{*}$ & .08 & $\begin{array}{l}\bar{X}=2.59 \\
\mathrm{~s}=.48\end{array}$ & $\begin{array}{l}\bar{X}=2.45 \\
s=.56\end{array}$ & $\mathrm{t}=1.11$ & .00 \\
\hline $\begin{array}{l}\text { 3. Engaging students } \\
\text { actively in observable } \\
\text { ways }\end{array}$ & $\begin{array}{l}\bar{X}=2.19 \\
s=.65\end{array}$ & $\begin{array}{l}\bar{X}=2.08 \\
s=.49\end{array}$ & $t=.85$ & .00 & $\begin{array}{l}\bar{X}=2.08 \\
s=.68\end{array}$ & $\begin{array}{l}\bar{X}=1.95 \\
\mathrm{~s}=.61\end{array}$ & $\mathrm{t}=.88$ & .00 \\
\hline
\end{tabular}


Sequel to Table 4.

\begin{tabular}{|c|c|c|c|c|c|c|c|c|}
\hline 1 & 2 & 3 & 4 & 5 & 6 & 7 & 8 & 9 \\
\hline $\begin{array}{l}\text { 4. Using a continuum } \\
\text { of strategies to } \\
\text { acknowledge appro- } \\
\text { priate behaviour }\end{array}$ & $\begin{array}{l}\bar{X}=2.26 \\
s=.85\end{array}$ & $\begin{array}{l}\bar{X}=2.17 \\
s=.59\end{array}$ & $\mathrm{t}=.53$ & .01. & $\begin{array}{l}\bar{X}=1.90 \\
s=.87\end{array}$ & $\begin{array}{l}\bar{X}=1.84 \\
s=.74\end{array}$ & $\mathrm{t}=.310$ & .01 \\
\hline $\begin{array}{l}\text { 5. Employing a } \\
\text { variety of techniques } \\
\text { to respond to inap- } \\
\text { propriate behaviour }\end{array}$ & $\begin{array}{l}\bar{X}=2.18 \\
s=.71\end{array}$ & $\begin{array}{l}\bar{X}=1.94 \\
s=.59\end{array}$ & $t=1.63$ & .02 & $\begin{array}{l}\bar{X}=1.83 \\
s=.83\end{array}$ & $\begin{array}{l}\bar{X}=1.79 \\
s=.65\end{array}$ & $\mathrm{t}=.15$ & .01 \\
\hline
\end{tabular}

$* \mathrm{p}<.05$.

\section{The Role of Certification Status in Teachers' Knowledge and Competency}

As shown in Table 5, teachers with certification in special education reported higher mean ratings of knowledge and competency across all evidence-based classroom management subscales with statistically significant differences when compared to those who were not in three of the five subscales: Maximising structure $(\mathrm{t}=2.29$, $\mathrm{df}=75, \mathrm{p}<.05$; $\left.\omega^{2}=.05\right)$; Using a continuum of strategies to acknowledge appropriate behaviour $\left(\mathrm{t}=2.83, \mathrm{df}=75, \mathrm{p}<.05 ; \omega^{2}=.08\right) ;$ Employing a variety of techniques to respond to inappropriate behaviour $\left(\mathrm{t}=3.15, \mathrm{df}=75, \mathrm{p}<.05 ; \omega^{2}=.11\right)$. Examination of Omega squared strength of association, however, indicated that although very little shared variability in aggregate was accounted for by being certified in special education, the subscale Employing a variety of techniques to respond to inappropriate behaviour had more than $10 \%$ of the variability in knowledge of the practice accounted for by special education certification.

The competency ratings were significantly different for the same three of the five evidence-based classroom management subscales: Maximising structure $(\mathrm{t}=3.55, \mathrm{df}=75$, $\left.\mathrm{p}<.05 ; \omega^{2}=.15\right)$; Using a continuum of strategies to acknowledge appropriate behaviour $\left(\mathrm{t}=4.09, \mathrm{df}=75, \mathrm{p}<.05 ; \omega^{2}=.21\right) ;$ Employing a variety of techniques to respond to inappropriate behaviour $\left(\mathrm{t}=4.07, \mathrm{df}=75, \mathrm{p}<.05 ; \omega^{2}=.21\right)$. More striking differences were found when examining mean competency ratings for these subscales by those who are certified in special education and those who were not. In all areas for evidencebased classroom management, teachers certified in special education reported higher perceptions of competency. Furthermore, examination of Omega squared strength of association indicated that all three of these subscales have ratings for which more than $10 \%$ of the variability is accounted for by special education certification. 
Table 5

Means, Standard Deviations and Test of Means for Teachers' Knowledge (K) and Competency (C) Ratings for Each Subscale by Certification Status in Special Education

\begin{tabular}{|c|c|c|c|c|c|c|c|}
\hline Subscales & 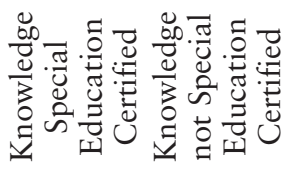 & 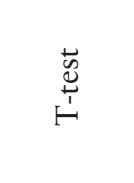 & 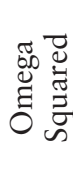 & 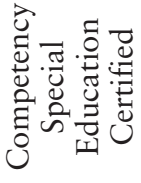 & 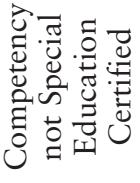 & 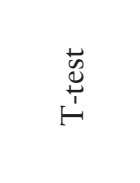 & 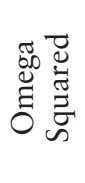 \\
\hline $\begin{array}{l}\text { 1. Maximising } \\
\text { structure }\end{array}$ & $\begin{array}{ll}\bar{X}=2.70 & \bar{X}=2.41 \\
s=.47 & s=.62\end{array}$ & $\mathrm{t}=2.29 \%$ & .05 & $\begin{array}{l}\bar{X}=2.82 \\
\mathrm{~s}=.25\end{array}$ & $\begin{array}{l}\bar{X}=2.51 \\
\mathrm{~s}=.51\end{array}$ & $\mathrm{t}=3.55^{*}$ & .15 \\
\hline $\begin{array}{l}\text { 2. Posting, teaching, } \\
\text { reviewing, monito- } \\
\text { ring and reinforcing } \\
\text { expectations }\end{array}$ & $\begin{array}{ll}\bar{X}=2.63 & \bar{X}=2.38 \\
s=.54 & \mathrm{~s}=.54\end{array}$ & $t=1.98$ & .04 & $\begin{array}{l}\bar{X}=2.65 \\
s=.56\end{array}$ & $\begin{array}{l}\bar{X}=2.43 \\
\mathrm{~s}=.49\end{array}$ & $t=1.86$ & .03 \\
\hline $\begin{array}{l}\text { 3. Engaging students } \\
\text { actively in observable } \\
\text { ways }\end{array}$ & $\begin{array}{ll}\bar{X}=2.24 & \bar{X}=2.05 \\
s=.50 & \mathrm{~s}=.59\end{array}$ & $t=1.42$ & .01 & $\begin{array}{l}\bar{X}=2.13 \\
\mathrm{~s}=.58\end{array}$ & $\begin{array}{l}\bar{X}=1.94 \\
s=.67\end{array}$ & $t=1.26$ & .01 \\
\hline $\begin{array}{l}\text { 4. Using a continuum } \\
\text { of strategies to } \\
\text { acknowledge appro- } \\
\text { priate behaviour }\end{array}$ & $\begin{array}{ll}\overline{\mathrm{X}}=2.48 & \overline{\mathrm{X}}=2.03 \\
\mathrm{~s}=.52 & \mathrm{~s}=.77 \\
& \\
\end{array}$ & $\mathrm{t}=2.82 *$ & .08 & $\begin{array}{l}\bar{X}=2.29 \\
s=.68\end{array}$ & $\begin{array}{l}\bar{X}=1.59 \\
s=.75\end{array}$ & $\mathrm{t}=4.09 *$ & .21 \\
\hline $\begin{array}{l}\text { 5. Employing a } \\
\text { variety of techniques } \\
\text { to respond to inap- } \\
\text { propriate behaviuor }\end{array}$ & $\begin{array}{ll}\bar{X}=2.33 & \bar{X}=1.87 \\
s=.50 & s=.68\end{array}$ & $t=3.15^{*}$ & .11 & $\begin{array}{l}\bar{X}=2.20 \\
s=.60\end{array}$ & $\begin{array}{l}\bar{X}=1.56 \\
s=.71\end{array}$ & $t=4.07^{*}$ & .21 \\
\hline
\end{tabular}

\section{Discussion}

This study investigated teachers' self-reported knowledge of and competency in using evidence-based practices in classroom management. In addition, the role of preservice and/or in-service experiences was explored. Notable findings of this study include significant relationships between teachers' ratings of knowledge and competency with specific evidence-based classroom management practices. Teachers who reported working in a school that implements PBIS and those with certification in special education had descriptively higher mean knowledge and competency ratings when compared to those without such statuses. Finally, for all subscales and practices, teachers reported most of their learning of evidence-based classroom management skills coming from in-service experiences.

\section{The Relationship Between Knowledge and Competency Ratings}

The moderate to strong positive direct correlations between perceived knowledge of and competency in evidence-based classroom management indicate that, in general, as teachers' perceived knowledge of a practice increases, perceived competency in using the strategy also increases. Teachers perceive themselves to be most competent in skills related to structure and expectations. This finding is consistent with what Shook (2012) found in her investigation about proactive and reactive classroom management practices 
used by teachers as confirmed by direct observations. The strong relationship between knowledge and competence, however, does not mean these teacher attributes are interchangeable. That is, self-reported knowledge of a strategy does not necessarily translate into perceived competency using the strategy, nor does perceived competency indicate that the teacher has knowledge of the practice. In four of the five subscales, for instance, teachers rated their knowledge of evidence-based classroom management practices higher than their competency. This finding is consistent with that of Begeny and Martens (2006) who asserted that knowing a practice does not equate to its confident and accurate use.

\section{Learning Evidence-Based Classroom Management Practices}

Teachers reported that the majority of their learning about all of the evidence-based classroom management practices comes from in-service sources as opposed to pre-service experiences. These results are consistent with the work of other researchers (Merrett \& Wheldall, 1993; Smart \& Igo, 2010) who reported that pre-service preparation programmes are not primary sources of teachers' classroom management capacity. Teacher's limited knowledge about the five critical elements of evidence-based classroom management practices coming from pre-service sources was related to the findings of the National Council on Teacher Quality (2014) that found almost $80 \%$ of teacher preparation programmes addressed two of the five subscales.

\section{PBIS School Status}

As mentioned previously, effective classroom management practices as determined by are essential components of the universal level of supports provided within the PBIS framework. The evidence-based practices determined by Simonsen and her colleagues (2008) offer teachers an insight as to practices that have shown positive effects in real classrooms in multiple research investigations. At the subscale level, teachers who worked in a PBIS school reported statistically significantly higher knowledge ratings for the posting, teaching, reviewing, monitoring and reinforcing expectations subscale when compared to respondents who do not identify an affiliation with a PBIS school. The difference is logical given the PD in classroom management provided to teachers as part of the PBIS framework. It is also feasible that teachers who work in PBIS schools experience a prominent emphasis on classroom management. This finding also relates to the work of Ross, Romer and Horner (2012), who found that randomly-selected elementary school that worked in schools that implement PBIS with fidelity self-reported increased efficacy as well as usage of evidence-based classroom management practices, such as teaching expectations and providing reinforcement, when compared to those who did not teach in such a school.

\section{Certification Status in Special Education}

Both knowledge and competency ratings of teachers who were certified in special education were statistically significantly higher than those who were not for the same three of the five areas (Maximising structure; Using a continuum of strategies to acknowledge appropriate behaviour; Employing a variety of techniques to respond to inappropriate behaviour). Noteworthy findings include certification status in special education 
accounted for approximately $11 \%$ of the variance in knowledge ratings for employing a variety of techniques to respond to inappropriate behaviour. For teachers' competency ratings, being certified in special education accounted for approximately $15 \%$ of the variability for maximising structure and $21 \%$ for the using a continuum of strategies to acknowledge appropriate behaviour and employing a variety of techniques to respond to inappropriate behaviour subscales. These trends lend support for the assertion that special educators often receive more preparation in the area of classroom management than their general education counterparts (Oliver \& Reschly, 2010; Tillery et al., 2010), which may influence special educators' ratings of knowledge and competency with evidence-based strategies in this domain due to perceived preparedness. However, given the inclusive nature of today's classrooms, it is imperative that general educators also receive instruction in their preparation programmes that emphasise effective evidencebased classroom management techniques.

\section{Conclusions and Future Directions}

This study supplements extant literature in two very important ways. First, teachers' self-reported knowledge and competency related to specific evidence-based classroom management subscales were addressed. Second, the learning sources for these particular strategies were identified so as to understand at what point in their career teachers come to learn such skills. One limitation of the current study that must be considered is its reliance on self-report data, which inherently risks biased or inaccurate recall, as well as over-estimation of preparedness and confidence (Housego, 1990) given no observation data (Reupert \& Woodcock, 2010). One must also consider the possible recency effects in estimating when the skills were learned, as well as unknown levels of implementation fidelity for those who reported working in a PBIS school. The limited response rate and the specificity of the respondents from New York's public schools must also be factored in when generalising the study's findings to other teacher populations or schools that define grade bands differently than presented in the current study. Future investigations should explore specific grade band correlations between teachers' knowledge of and competency with evidence-based classroom management practices now that the general trend has been ascertained in this study.

Despite these limitations, the results of this study have important implications for both research and practice. Teachers' self-reported knowledge of, competency with, and actual application of evidence-based classroom management practices appear to be related to certification area and service environment. Although respondents were not asked to identify their teacher preparation source or institution in order to maintain anonymity and comfort taking the survey, the results suggest that teachers develop skills in the area of classroom management via both pre-service and in-service sources, with the latter source being more prominent according to self-report. Therefore, it is imperative that teacher preparation programmes provide coordinated coursework and fieldwork experiences through which teachers can be prepared in evidence-based classroom management skills and provided with a foundation to access future opportunities to apply and enhance skills in this important domain via in-service sources. With such comprehensive opportunities, teachers may deem themselves equipped with effective strategies to support students' academic and social outcomes that so heavily depend on teachers' knowledge and competency. 


\section{References}

Auld, R. G., Belfiore, P. J., \& Scheeler, M. C. (2010). Increasing pre-service teachers' use of differential reinforcement: Effects of performance feedback on consequences for student behavior. Journal of Behavior Education, 19, 169-183.

Begeny, J. C., \& Martens, B.K. (2006). Assessing pre-service teachers' training in empirically validated behavioral instruction practices. School Psychology Quarterly, 21, 262-285.

Brophy, J. E., \& McCaslin, M. (1992). Teachers' reports of how they perceive and cope with problem students. Elementary School Journal, 93(1), 2-68.

Brownell, M. T., Smith, S. W., McNellis, J. R., \& Miller, M. D. (1997). Attrition in special education: Why teachers leave the classroom and where they go. Exceptionality, 7(3), 143-155.

Capizzi, A. M., Wehby, J. H., \& Sandmel, K. (2010). Enhancing mentoring of teacher candidates through consultative feedback on videotaped instructional delivery. Teacher Education and Special Education, 33(3), 191-212.

Clunies-Ross, P., Little, E., \& Kienhuis, M. (2008). Self-reported and actual use of proactive and reactive classroom management strategies and their relationship with teacher stress and student behavior. Educational Psychology, 28(6), 693-710.

Evertson, C. M., \& Weinstein, C. S. (2006). Classroom management as a field of inquiry. In C. M. Evertson \& C. S. Weinstein (Eds.), Handbook of classroom management: Research, practice, and contemporary issues (pp. 1041-1062). Mahwah, NJ: Lawrence Erlbaum Associates.

Frey, A. J., Park, K. L., Browne-Ferrigno, T., \& Korfhage, T. L. (2010). The social validity of program-wide positive behavior support. Journal of Positive Behavior Interventions, 12(4), 222-235.

Hamill, L. B, \& Dever, R. B. (1998). Preparing for inclusion: Secondary teachers describe their professional experiences. American Secondary Education, 27(1), 18-26.

Horner, R. H., \& Sugai, G. (2000). School-wide behavior support: An emerging initiative. Journal of Positive Behavioral Interventions, 2, 231-233.

Housego, B. E. (1990). A comparative study of student teachers' feelings of preparedness to teach. Alberta Journal of Educational Research, 36, 223-239.

Kennedy, M. J., \& Thomas C. N. (2012). Effects of content acquisition podcasts to develop preservice teachers' knowledge of positive behavioral interventions and supports. Exceptionality, 20, 1-19.

Leana, C. R. (2011). The missing link in school reform. Stanford Social Innovation Review, Fall Edition, 30-35.

Levine, A. (2006). Educating school teachers. Washington, DC: The Education Schools Project.

McIntosh, K., Chard, D. J., Boland, J. B., \& Horner, R. H. (2006). Demonstration of combined efforts in school-wide academic and behavioral systems and incidence of reading and behavior challenges in early elementary grades. Journal of Positive Behavior Interventions, 8(3), 146-154.

McIntosh, K., Horner, R. H., Chard, D., Dickey, C. R., \& Braun, D. H. (2008). Reading skills and function of problem behavior in typical school settings. The Journal of Special Education, 42(3), 131-147.

Merrett, F., \& Wheldall, K. (1993). How do teachers learn to manage classroom behavior? A study of teachers' opinions about their initial training with special reference to classroom behavior management. Educational Studies, 19, 91-106. 
Moore-Partin, T. C., Robertson, R., Maggin, D. M., Oliver, R. M., \& Wehby, J. H. (2010). Using teacher praise and opportunities to respond to promote appropriate student behavior. Preventing School Behavior, 54(3), 172-178.

National Council on Teacher Quality. (2014). Training our future teachers: Classroom management. Retrieved January 26, 2014, from www.nctq.org/teacherPrep

Oliver, R. M., \& Reschly, D. J. (2007). Effective classroom management: Teacher preparation and professional development. Washington, DC: National Comprehensive Center for Teacher Quality.

Oliver, R. M., \& Reschly, D. J. (2010). Special education teacher preparation in classroom management: Implications for students with emotional and behavioral disorders. Behavioral Disorders, 35(3), 188-199.

Oliver, R. M., Wehby, J. H., \& Reschly, D. (2011). The effects of teachers' classroom management practices on disruptive or aggressive student behavior. Retrieved April 6, 2013, from http://campbellcollaboration.org

O’Neill, S., \& Stephenson, J. (2012). Does classroom management coursework influence pre-service teachers' perceived preparedness or confidence? Teaching and Teacher Education, 28, 1131-1143.

Reinke, W. M., Stormont, M., Herman, K. C., Puri, R., \& Goel, N. (2011). Supporting children's mental health in schools: Teacher perceptions of needs, roles, and barriers. School Psychology Quarterly, 26, 1-13.

Reupert, A., \& Woodcock, S. (2010). Success and near misses: Pre-service teachers' use, confidence and success in various classroom management strategies. Teaching and Teacher Education, 26, 1261-1268.

Ross, S. W., Romer, N., \& Horner, R. H. (2012). Teacher well-being and the implementation of school-wide positive behavior interventions and supports. Journal of Positive Behavior Interventions, 14(2), 118-128.

Shook, A. C. (2012). A study of preservice educators' dispositions to change behavior management strategies. Preventing School Failure, 56(2), 129-136.

Simonsen, B., Fairbanks, S., Briesch, A., Myers, D., \& Sugai, G. (2008). Evidencebased practices in classroom management: Considerations for research to practice. Education and Treatment of Children, 31(3), 351-380.

Simonsen, B., MacSuga, A. S., Fallon, L. M., \& Sugai, G. (2012). Teacher self-monitoring to increase specific praise rates. Journal of Positive Behavior Interventions. doi: 10.1177/1098300712440453

Simonsen, B., Myers, D., \& DeLuca, C. (2010). Teaching teachers to use prompts, opportunities to respond, and specific praise. Teacher Education and Special Education, 33(4), 300-318.

Smart, J. B., \& Igo, L. B. (2010). A grounded theory of behavior management strategy selection, implementation, and perceived effectiveness reported by first-year elementary teachers. The Elementary School Journal, 110(4), 567-584.

Sugai, G. (2009). School-wide positive behavior support and response to intervention. Retrieved February 12, 2013, from http://www.rtinetwork.org/learn/behaviorsupports/schoolwidebehavior

Tillery, A. D., Varjas, K., Meyers, J., \& Smith Collins, A. (2010). General education teachers' perceptions of behavior management and intervention strategies. Journal of Positive Behavior, 12(2), 86-102. 
Walker, H. M., \& Severson, H. H. (2002). Developmental prevention of at-risk outcomes for vulnerable antisocial children and youth. In K. L. Lane, F. M., Gresham \& T. E. O'Shaughnessy (Eds.), Interventions for children with or at risk for emotional and behavioral disorders (pp. 177-194). Boston: Allyn \& Bacon.

Westling, D. L. (2010). Teachers and challenging behavior: Knowledge, views, and practices. Remedial and Special Education, 31(1), 48-63.

Correspondence concerning this paper should be addressed to Laura Ficarra, PhD, University at Albany, State University of New York, 1400 Washington Ave. ED233, Albany, N.Y., U.S.A. 12222. Email: LFicarra@albany.edu

\section{Appendix A}

Evidence-based Classroom Management Skills Compiled by Simonsen et al. (2008)

\begin{tabular}{ccc}
\hline $\begin{array}{c}\text { Critical Elements } \\
\text { (Concept/Subscale) }\end{array}$ & Practices & Descriptions \\
\hline 1 & 2 & 3 \\
\hline
\end{tabular}

1. Maximising structure a. Establish structure through A teacher's involvement and defining teacher-directed activities of routines

b. Physically arrange the class- A teacher is about the purposeful room to minimise distractions layout of furniture and visuals to minimise crowding and distraction

\begin{tabular}{|c|c|c|}
\hline \multirow[t]{2}{*}{$\begin{array}{l}\text { 2. Posting, teaching, } \\
\text { reviewing, monitoring } \\
\text { and reinforcing } \\
\text { expectations }\end{array}$} & $\begin{array}{l}\text { a. Develop and directly teach } \\
\text { expectations }\end{array}$ & $\begin{array}{l}3-5 \text { positively-stated expectations } \\
\text { are visually posted, directly taught } \\
\text { to students (and reviewed) via } \\
\text { lessons, examples and non-examples }\end{array}$ \\
\hline & $\begin{array}{l}\text { b. Actively supervise in all } \\
\text { areas; provide feedback on } \\
\text { expectations }\end{array}$ & $\begin{array}{l}\text { A teacher monitors, moves and looks } \\
\text { around, interacts with students, pro- } \\
\text { vides error correction or reinforce- } \\
\text { ment for behaviour based on expec- } \\
\text { tations }\end{array}$ \\
\hline \multirow[t]{6}{*}{$\begin{array}{l}\text { 3. Engaging students } \\
\text { actively in observable } \\
\text { ways }\end{array}$} & $\begin{array}{l}\text { a. Provide opportunities to } \\
\text { respond }\end{array}$ & $\begin{array}{l}\text { A teacher prompts students in a way } \\
\text { that requires their response/engage- } \\
\text { ment }\end{array}$ \\
\hline & b. Use response cards & $\begin{array}{l}\text { Response system for all students } \\
\text { used to answer a teacher's question }\end{array}$ \\
\hline & c. Directly instruct skills & $\begin{array}{l}\text { A teacher's presentations academic } \\
\text { and social skills content explicitly } \\
\text { and systematically }\end{array}$ \\
\hline & $\begin{array}{l}\text { d. Use computer-assisted } \\
\text { instruction }\end{array}$ & $\begin{array}{l}\text { A teacher uses technology to indivi- } \\
\text { dualise instruction or have students } \\
\text { practice skills }\end{array}$ \\
\hline & e. Use class-wide peer tutoring & $\begin{array}{l}\text { Students are paired as tutoring } \\
\text { partners for rapid skill practice } \\
\text { receiving immediate error correction }\end{array}$ \\
\hline & f. Use guided notes & $\begin{array}{l}\text { Outlines of notes on which students } \\
\text { need to fill in missing information }\end{array}$ \\
\hline
\end{tabular}

Sequel to Appendix A see on p. 87. 
Sequel to Appendix A.

1 2 3

4. Using a continuum a. Provide behaviour-specific A teacher verbalises a reinforcing of strategies to acknow- praise ledge appropriate behaviour

\begin{tabular}{l} 
b. Offer class-wide contin- \\
gencies \\
\hline c. Develop behavioural \\
contracts
\end{tabular}
statement to students about their appropriate behaviour Groups of students can earn a reward for meeting a common goal Written document developed for behaviour and consequences (the outcome of appropriate behaviour and vice versa)

d. Develop token economies Earned tokens to be redeemed for a prize or privilege

5. Employing a variety a. Use error correction for of techniques to res- academic and social behaviour pond to inappropriate Brief statement summarising an inap-

behaviour

b. Give performance feedback propriate behaviour and what the student should do instead Class-wide data are used to set goals with students for which they can earn rewards

c. Provide differential reinforce- Appropriate behaviour is reinforced ment to decrease the inappropriate behaviour

d. Practise planned ignoring A teacher purposefully withholds attention as a consequence when attention motivates inappropriate behaviour

e. Use of response cost A student loses tokens or privileges when an inappropriate behaviour is displayed

f. Provide time out from A student is away from reinforcing reinforcement people, locations and/or objects

Appendix B

\begin{tabular}{|c|c|c|}
\hline Scale & Critical Element/Subscale & $\begin{array}{l}\text { bach's Alpha } \\
\text { Coefficient }\end{array}$ \\
\hline \multirow{6}{*}{ 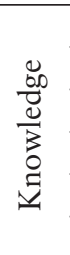 } & Overall & .851 \\
\hline & Maximising structure & .554 \\
\hline & Posting, teaching, reviewing, monitoring and reinforcing expectations & .345 \\
\hline & Engaging students actively in observable ways & .772 \\
\hline & Using a continuum of strategies to acknowledge appropriate behaviour & .790 \\
\hline & Employing a variety of techniques to respond to inappropriate behaviour & .803 \\
\hline \multirow{6}{*}{ 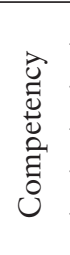 } & Overall & .859 \\
\hline & Maximising structure & .384 \\
\hline & Posting, teaching, reviewing, monitoring, and reinforcing expectations & .317 \\
\hline & Engaging students actively in observable ways & .781 \\
\hline & Using a continuum of strategies to acknowledge appropriate behaviour & .764 \\
\hline & Employing a variety of techniques to respond to inappropriate behaviour & .771 \\
\hline
\end{tabular}

